\title{
EL CINE QUE HABITA LA PINTURA
}

Teresa Sorolla-Romero

Universitat Jaume I

En El molino y la cruz (Mlyn i krzyz, Lech Majewski, 201 1), la mirada de la cámara es silente, discreta. No es su recorrido por el profílmico aquello que desvela una intención discursiva, sino la misma puesta en escena la que habla. Si del cine se ha escrito que hacía echar a andar a la pintura, esta recreación cinematográfica del óleo sobre tabla de roble Camino del Calvario (1564) de Brueghel el Viejo detiene el cine para hablar de pintura. El filme rehúye la categorización de biopic de Pieter Brueghel, pues el pintor flamenco no solamente está presente en el discurrir del relato sino que interviene de forma activa en él, como narrador privilegiado, o más bien maestro de ceremonias que habita su propia ficción y va dirigiendo la composición del resto de personajes en el espacio diegético, que pese a su componente exterior funciona a modo de limitado proscenio. La pintura tampoco supone una cita puntual enmarcada en un universo fílmico mayor, sino que va generándose en su seno, constituyéndolo en su totalidad, a medida que se van desarrollando determinadas escenas protagonizadas por unos cuantos de los personajes retratados en la pintura de Brueghel. Una familia de molineros, un joven linchado y expuesto por soldados españoles y su joven amante que le llora, el propio pintor (Rutger Haver), su esposa, su patrón Nicolaes Jonghelinck (Michael York) y finalmente un trasunto de virgen María (Charlotte Rampling) doliente por la ejecución de su hijo. Su crucifixión a manos de las tropas hispánicas responde a la represión del protestantismo, contexto según el cual se reinterpreta el camino al calvario y la crucifixión tanto en el lienzo original como en el filme. 

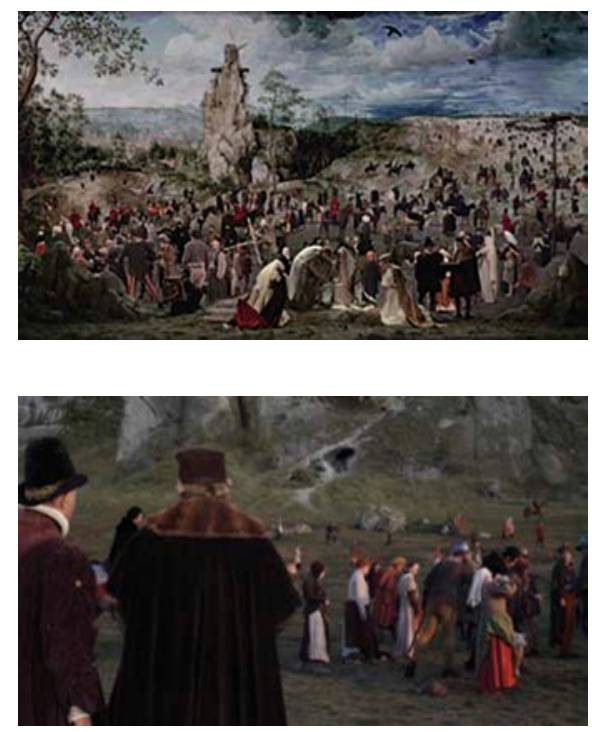

Fotogramas de El molino y la cruz.

El parco desarrollo narrativo de diversos episodios va configurando la disposición de unas pocas escenas de la pintura, mientras un nutrido y cuidadosamente coreografiado grupo de secundarios pulula armoniosamente ocupando la periferia del encuadre. De tanto en tanto Brueghel toma esbozos, reflexiona y reorganiza parcialmente tales escenas, justificando el simbolismo de la representación a su patrón. Con ello, se sitúa a medio camino entre objeto y sujeto de la representación, superando los atributos de los personajes convencionales y adquiriendo capacidades de meganarrador. Es, precisamente, en los momentos en que Brueghel detiene la acción para pensarla, cuando la cámara se mueve. El artista, acompañado de Jonghelinck, que se lamenta de la cruenta represión de la monarquía sobre su pueblo y expresa su anhelo de detener el tiempo, levanta seriamente una mano. Las aspas del molino y su maquinaria interna dejan de girar $y$, a excepción del molinero, que se asoma desde lo alto contemplando la multitud que se dirige a crucificar a tres hombres, todo se detiene. Un travelling hacia la izquierda -que contradice el sentido de la lectura occidental expresando un ir al revés, un volver-va recorriendo la disposición de personajes que se reconocen en la escena del lienzo. Como avanzábamos más arriba, el cine se detiene para hablar de pintura. Superando el reclamo puntual de una intertextualidad o la mera explicación historiográfica de su razón de ser, suspende la narrativa para explorarla, para re-crearla, para hacer justicia a su complejidad compositiva, a la estratificación temporal -indesligable de la simbólica que anida en ella. Desglosándola, rescata para la 
mirada del espectador aquello que Brueghel hacía pasar desapercibido.

Más allá de la autorreferencialidad de la enunciación, plano a plano, el formalismo y el ritmo pausado en cada encuadre ensalzan las marcadas cualidades pictóricas del filme, resaltadas además por una textura que aplana la profundidad de campo sin renunciar por ello al componente atmosférico de la niebla, la hierba o el contraste de lo rocoso con el cielo. Los planos fijos orientan constantemente al espectador con referentes espaciales -el molino, la rueda levantada sobre un poste de madera, el cráneo de caballo- que atan desde cualquier punto de vista al universo diegético del lienzo, fuera del cual -si bien los personajes hacen referencia, indirectamente, a España- parece no existir mundo que funcione según una lógica -y ritmo- diferente al amargo medievalismo con regusto de cuento que todavía a mediados del siglo XVI arrastra la aldea retratada. La cámara calla desde su perfecta colocación, que permite que la composición, el montaje interno, se explique a sí mismo. Habiéndose situado en puntos excelentemente ventajosos, que favorecen la observación de llamativos detalles sobre el conjunto sin cortar a planos detalle. El punto de vista estático prevalece sobre el montaje analítico. De hecho, y aunque aparecen angulaciones aberrantes bajo el molino y puntos de vista "flotantes" acompañando al cadáver en alto que los cuervos devoran, también abundan los límites que la cámara no cruza, en forma, por ejemplo, de dinteles de puertas obsesivamente fregados por mujeres y constantemente pisoteados por niños que corretean entrando y saliendo de campo.

Una mirada particularmente cinematográfica atiende, en cambio, la imagen de Cristo envuelto en una sábana a la entrada de la cueva, sobre una especie de camilla. La angulación permite solamente atisbar los pies ensangrentados y sucios, alternados mediante montaje con un primer plano de su madre. La conmoción de la mujer es vehiculada, así, por la fragmentación del montaje. Particularmente cinematográfico será, también, el cierre del filme. Tras la tormenta nocturna que resuena y relampaguea en la noche, amanece de nuevo y el pueblo retoma su lenta cadencia vital, cuya última imagen condensa en un grupo de aldeanos danzando. Un fundido a negro da paso a un detalle del lienzo original, que el espectador reconoce por insistencia previa del relato. La virgen llora, rodeada de figuras cuya pose hemos visto organizar al arranque del filme. El encuadre se retira poco a poco, dejando entrar en campo el resto del lienzo a medida que se distancia del mismo mediante un travelling oblicuo. La retirada permite ver, colgada al lado de Camino del Calvario, la celebérrima Torre de Babel de Brueghel (1563), a la cual la mirada cinematográfica le presta la justa atención para que entre en campo sin aproximarse a ella. En el lento retroceder de la cámara, el primero queda a la izquierda del plano mientras, 
significativamente, el centro de la imagen lo ocupan las sucesivas puertas de galerías contiguas del Kunsthistorisches Museum de Viena.

Así, una vez que el cine ha habitado la pintura, ha hurgado en su vida, se sale de la misma para poner en evidencia su quietud en la pared del museo, ocupado únicamente por el arrastre fantasmal de la cámara, que subraya una cierta ausencia de vida. El mutismo de las obras circundantes plantea sendos interrogantes respecto a qué hallaría un explorador sumergido en cada uno de los lienzos.

La obra de Brueghel, convocada entre otros cineastas por Andrei Tarkovski - Lars von Trier, aparece también -junto dispares referencias que abarcan desde Giorgio de Chirico a Roy Lichtenstenin- en la cinematografía de Dario Argento, tal y como analiza el texto Los contornos del miedo. La huella del arte pictórico en el giallo italiano. Agustín Rubio y Antonio Loriguillo explican cómo, al inicio de El síndrome de Stendhal (La sindrome di Stendhal, 1996), la conciencia de una protagonista desmayada se traslada al interior del Paisaje con la caída de ĺcaro (1554-1555), de nuevo para proponer una indagación inevitablemente subjetiva del mismo. Si en Camino del Calvario Cristo llevando la cruz permanecía casi oculto entre la algarabía de figuras que le rodean, de ĺcaro únicamente se pueden ver las piernas saliendo del agua, arrinconadas respecto al resto de la composición que privilegia otros elementos como el campesino que labra en primer término, la orografía del terreno o el barco. Del mismo modo que el observante de las pinturas de Brueghel debe recorrerlas con atención para identificar los motivos prometidos en el título, el artículo mencionado excava en la prolífica amalgama postmoderna del giallo, poniendo a prueba y dando razón de su preconcebida condición de pastiche con voluntad, en algunos casos, de sintética puesta en diálogo de la mediática cultura de masas con referentes universales del mundo del Arte.

Si el artículo termina enumerando las "verborreicas" citas pictóricas que El síndrome de Stendhal lleva a cabo en sus títulos de crédito finales atribuyendo su cantidad, precisamente, a la facilidad de hibridación postmoderna, en el opening de El joven papa-de creador también italiano- (The Young Pope, Paolo Sorrentino, 2016) las obras escogidas para formar parte de la galería que el protagonista recorre son enmarcadas, enaltecidas e iluminadas de modo que su discurrir al paso del pontífice ficticio reclama interpretación. A ello nos dedicamos en el artículo $A$ lo largo de la atalaya: el travelling descreído del opening de The Young Pope (Paolo Sorrentino, 2016).

El recorrido que propone el arranque de El joven papa requiere una fragmentación y puesta en secuencia que traiga al presente de la representa- 

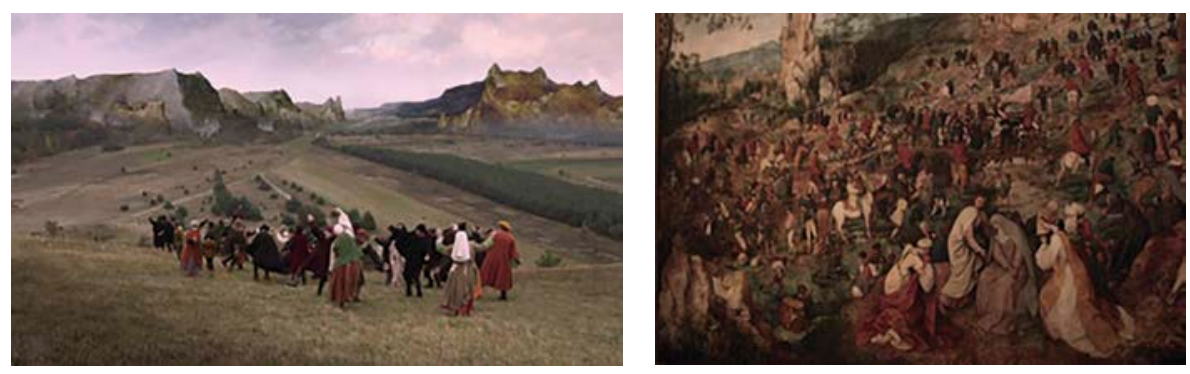

Escena final de El molino y la cruz, en la que la enunciación abandona el interior del lienzo para apartarse del mismo en el interior del museo, antes de fundir con los créditos finales.

ción las obras del pasado para reformularlas integrándolas en un discurso nuevo. El montaje, recurso articulador por excelencia del lenguaje cinematográfico -en contraste con el pictórico reside también en el corazón de la reinterpretación fílmica de la Batalla de Issos estudiada por Víctor Mínguez en La huida de un rey. Reflejos de un mosaico pompeyano en las versiones de Alejandro de Robert Rossen (1956) y Oliver Stone (2005). La escena de la contienda en en el mosaico pompeyano del que arranca el texto, así como la recreación de la misma en los filmes de Rossen y Stone, nacen de la puesta en conjunto de una constelación de fragmentos homogeneizados mediante el montaje. Lo climático de la huida del rey persa ante el encuentro con Alejandro continúa constituyendo el epicentro de las narraciones contemporáneas. El cine, nacido -a diferencia de otras obras representativas de la batalla- tras el descubrimiento arqueológico del mosaico, rescata en diversos planos partes del mismo en forma de los rostros, indumentaria y gestos de sus protagonistas. En la capacidad de dilatación del cine como medio narrativo sobreviven, así, los cuerpos escorzados y las miradas desorbitadas de la imagen seminal, magnificados por su capacidad espectacular que endiosa y privilegia el punto de vista del espectador a la par que inviste (si cabe, más) épicamente la figura de Alejandro.

Precisamente la supervivencia de los gestos patéticos en el gélido, minimalista y en artificialmente nostálgico universo de Black Mirror (Charlie Brooker, 2011-) constituye el principal interrogante formulado por Iván Pintor en Capital de la emoción, emociones del capital. Continuidad y supervivencia iconográfica de los gestos de sumisión y privación de libertad en Black Mirror. La urdimbre teórica del artículo cose el rastreo de determinada gestualidad violenta que, sintomáticamente, sobrevive desde la Anti- 
güedad hasta la ciencia-ficción para emerger como indicio de malestares profundos. Tales incomodidades explotan trágicamente en los universos de la serie, falsamente controlados a través discretas y elegantes tecnologías implantadas, en muchos casos, como inadvertidas reguladoras de la subjetividad humana que evacúan la responsabilidad del sujeto respecto a sus recuerdos, temores, relaciones sociales, aspiraciones, etc.

Una cierta unidad autoral vincula los diversos episodios de Black Mirror, que transitan entre la ciencia-ficción, el thriller e incluso lo melodramático sin perder su consistencia. Del mismo modo que en el artículo se buscan los referentes visuales de las imágenes de dolor en los estratos de siglos y siglos de representación de imágenes de todo tipo, Ángel Justo expone en Retrato de cineasta pintando en el estudio: relaciones entre pintura y cine en David Lynch: The Art Life (2016) cómo el documental va extendiendo, desde el aprovechamiento de los recursos del lenguaje audiovisual, las particularidades del arte plástico de David Lynch. Los pliegues que conectan experiencias de la niñez y juventud temprana del polifacético creador con la razón de ser de su praxis artística -tal y como explica Ángel Justo- adquieren forma de un heterogéneo magma iconográfico en el que confluyen obras de arte que han influenciado la perturbadora estética de Lynch, imágenes vernáculas de su propio pasado y creaciones propias -indesligables ya del pasado que anida en las anteriores- que dialogan con esta mencionada memoria visual, así como con la memoria narrativa que va desplegando el cineasta mediante su propia voz, con una cercanía de nuevo casi doméstica que casa con la idea del documental como legado a su hija pequeña.

Si algo se revuelve entre los intersticios de todos los trabajos del Dossier es la naturaleza resbaladiza de las imágenes y su quebradizo apego a verdades cambiantes según la época que las alumbra y la que las mira, la que las siente suyas y la que las analiza, rescata, demoniza o reabsorbe. En La representación y la mirada: retrato pictórico y falsa identidad en el Cine Negro norteamericano de los años cuarenta, Carlos Cuéllar da cuenta de lo aurático del retrato, imagen reveladora e insuficientemente sustitutiva de una ausencia por excelencia. La potencia de lo sugerido por los protagónicos lienzos de Laura y La mujer del cuadro reside, en realidad, en la subjetividad de los hombres que los contemplan, que buscan definirse desde su relación con las mujeres encuadradas. La entidad atribuida al ideal femenino imaginado a partir de su reflejo enmarcado antecede y supera a la de las mujeres. Tal y como el autor defiende, los lienzos en torno a los cuales giran los filmes no sostienen, por ellos mismos, verdades, sino que plantean interrogantes que, más allá de las cavilaciones de los habitantes 
del universo diegético en cuestión, continúan siendo pensados hoy por la historiografía del cine.

En un suspiro que expresa un anhelo solamente posible desde la magia de la ficción, Jonghelinck se lamenta ante Brueghel: "si sólo el tiempo se parara...". Ante la imposibilidad de resolver el enigma de la representación tal y como lo hace el pintor en el filme-deteniendo el flujo temporal de su alrededor al levantar un brazo, para descomponerla y exprimir su riqueza parte por parte- proponemos aproximarnos a la complejidad de la reapropiación mutua del lenguaje pictórico y cinematográfico convencidos de que, más que a modo de sencilla mise en abyme, ésta funciona como un nudo, un laberinto desdoblado y especular rico en trampantojos, en el cual resulta más estimulante asomarse a la complejidad de las reclamaciones, profanaciones y reverencias continuas entre ambos medios que atribuir diferentes modos de significar concretos, propios y estancos a la pintura y el cine. 